\title{
Surgical management of preauricular fistula based on plastic-reconstructive algorithm
}

\author{
Dini Widiarni Widodo, Hemastia Manuhara Harba'i \\ Department Otorhinolaryngology Head and Neck Surgery, \\ Cipto Mangunkusumo Hospital-Universitas Indonesia \\ Jakarta
}

\begin{abstract}
Background: Preauricular fistula is a congenital malformation of the six auditory hillocks during the development of auricle, when an imperfect fusion of the first arch tuberculum to other tuberculums occurred and generated a tract. It is characterized by a nodule or a dent located adjacent to the external ear. An infection will create a swollen area in front of ear auricles with pain and suppuration. Fistula extirpation should be carried out after the acute infection subsides. Purpose: To evaluate surgery techniques with the lowest complication and recurrence rate. Case report: Reporting 4 surgical cases of prearicular fistula treated by Plastic-Reconstructive ENT Head and Neck surgery, among 26 cases of preauricular fistula diagnosed between 2015 to 2017 in Cipto Mangunkusumo General Hospital. Methods: Searching literature through Pubmed, Wiley, Proquest and Google Schoolar with keywords of "Preauricular fistula AND surgical treatment". Further selection through clinical questions. Results: One journal presented a systematic review on the surgical outcome of preauricular sinus excision techniques. Reporting 4 cases treated by plastic-reconstructive surgery based on the systematic review above mentioned. Conclusion: The supra auricular approach could be recommended as a good technique for preauricular fistula, in particular for the infected and/or the recurrent cases.
\end{abstract}

Keywords: preauricular fistula, infection, fistulectomy

\begin{abstract}
ABSTRAK
Latar belakang: Fistel preaurikula adalah suatu kelainan malformasi kongenital, dimana tuberkulum arkus brakialis pertama tidak menyatu dengan tuberkulum lainnya, sehingga terbentuk sebuah traktus (saluran). Fistel preaurikula ditandai oleh adanya nodul atau cekungan yang tampak di dekat telinga luar. Bila terjadi infeksi biasanya menyebabkan daerah di depan daun telinga bengkak dan nyeri, serta bernanah. Ekstirpasi fistel sebaiknya dilakukan setelah infeksi akut mereda. Tujuan: Mengevaluasi teknik bedah dengan tingkat komplikasi dan kekambuhan terendah. Laporan kasus: Dilaporkan 4 kasus fistel preaurikula yang ditatalaksana oleh bedah THT-KL plastik-rekonstruksi, dari sejumlah 26 kasus yang datang berobat di RSUPN Cipto Mangunkusumo, antara Januari 2015 dan April 2017. Metode: Penelitian literatur melalui Pubmed, Wiley, Proquest, dan Google Schoolar dengan kata kunci "Preauricular fistula AND surgery treatment". Seleksi literatur lebih lanjut melalui pertanyaan klinis. Hasil: Didapati 1 jurnal yang menyajikan hasil operasi dari teknik bedah eksisi sinus preaurikular secara systematic review. Dilaporkan 4 kasus yang ditatalaksana dengan bedah plastik-rekonstruksi berdasarkan systematic review tersebut di atas. Kesimpulan: Pendekatan supra aurikula dapat direkomendasikan sebagai teknik bedah yang baik untuk penatalaksanaan fistel preaurikular, khususnya yang terinfeksi dan/atau berulang.
\end{abstract}

Kata kunci: fistel preaurikula, infeksi, fistulektomi. 
Corresponding Author: Dini Widiarni Widodo, MD ORL PhD, Plastic Reconstruction Consultant, Otorhinolaryngology Head and Neck Surgery Department, Cipto Mangunkusumo Hospital -Universitas Indonesia, Pangeran Diponegoro Street no.71, Central Jakarta 10430, Indonesia. Ph. +62816807230 . Email: dini_pancho@yahoo.com

\section{INTRODUCTION}

Preauricular fistula was first introduced by Van Heusinger in 1864 . The disorder is inherited in autosomal dominant incomplete, $25-50 \%$ occurs bilaterally. The literature mentions that in Asia the incidence reaches $1-10 \%$. There is no significant difference between the incidence of preauricular fistula in men and women. ${ }^{1}$

The theory stated the development of a preauricular fistula occurred from an imperfect fusion of the six auricular hillocks. (Figure 1). It is also termed as preauricular pit, preauricular sinus, preauricular tract, and preauricular cyst. ${ }^{1}$

Usually asymptomatic, preauricular fistula patients frequently seek treatment due to infection. Preauricular fistula appears in the form of small depressions or pits which are usually located in the anterior border of the ascending helix. The preauricular fistula is generally narrow, varies in length, but the orificium is usually short and small, protected

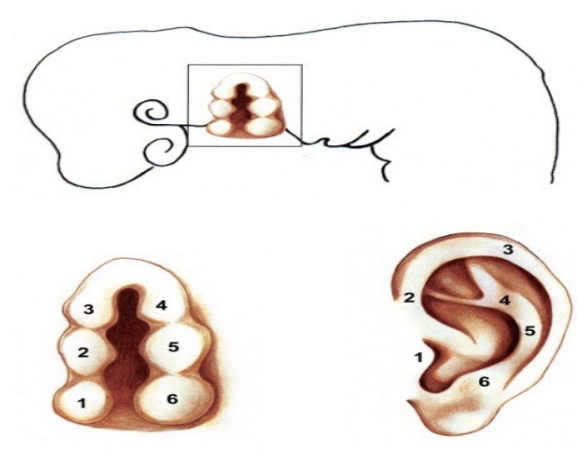

Figure 1. Ear development stage. ${ }^{2}$

(1) Tragus (2) Krus helix (3) Helix (4) Antihelix (5) Antitragus (6) Lobule and forked/bifurcated around the outer ear. The length of the fistula tract varies between 3 to $22 \mathrm{~mm}$. Methylene blue can be used to trace the tract. Fistulography as another method is performed by injecting the contrast liquid into the fistula. Fistula tract usually found on latero-superior and posterior of the facial nerve and parotid gland, and located close to the facial nerve. At the time of removing the fistula tract to the anterior -that extends to the border of the parotid gland-, it can cause trauma to the facial nerve. In some cases, the tract connects with the perichondrium of the ear cartilage. ${ }^{3}$

In the acute phase of preauricular fistula infection, adequate antibiotics against pathogens should be given, and drainage should be performed. Coatesworth et al. ${ }^{3}$ described techniques of preauricular abscess drainage using lacrimal probe.

Baatenburg de Jong, ${ }^{4}$ introduced a technique which is a modified technique of wide local excision. The procedure was introduced as an "inside-out" technique, and performed using a microscope. This method involves a small elliptical incision around the sinus pit. Stay sutures are placed to facilitate dissection of the tract and the sinus is opened. The sinus tract and its branches are then followed from the inside and outside (Figure 2). Baatenburg de Jong, ${ }^{4}$ reported $0 \%$ recurrence rate with this inside-out technique.

Other technique is radical wide local excision defined as supra-auricular approach. On this technique, the elliptical incision around the sinus orifice be extended higher upward to the pre- and supra-auricular temporal region. (Figure 3) This allows better surgical vision without adverse aesthetic consequences. ${ }^{5}$ 


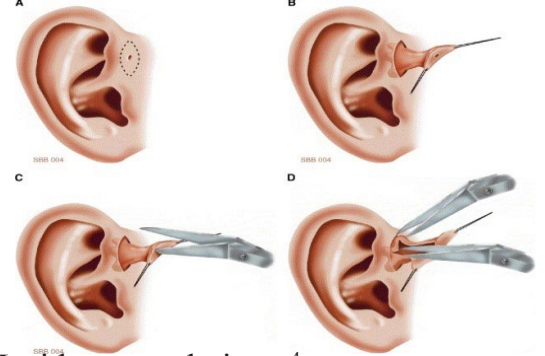

Figure 2. Inside-out technique. ${ }^{4}$

A: Creating an elliptical incision around the orificium of the fistula. B: Creating stitches around the orificium of the fistula as a handle for easy dissection of the fistula tract. C: Opening fistula channel with sharp scissors. D: Using a magnifying glass, a wall that has been stained with methylene blue ("inside") and the outer wall of the fistula tract is freed from the surrounding tissues.
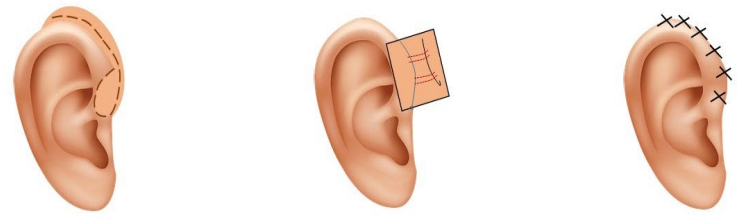

Figure 3. Supra-auricular approach and helix cartilage suture. ${ }^{5}$

Incomplete excision would result in recurrence of preauricular fistula. Up till now, there is no proven effective operation techniques which can completely excised preauricular fistula. Recurrence rate is quite high up to $20 \%{ }^{6,7}$

The closure procedures were classified into 3 categories: those involving primary closure only, those involving primary closure with wide undermining, and those involving auricular flap repairs. ${ }^{8,9}$

Primary closure with wide undermining is performed in large resected area. Tension could be avoided with wide undermining similar to a facelift procedure. The silicon drain is then inserted into the posterior side. The subcutaneous tissue was closed with primary suture. ${ }^{8,9}$
If the auricular cartilage was exposed during excision and the tissue defect was wide, the closure was executed by a posterior auricular transposition or rotation flap. The flap was transferred to the defect by a rotation of up to $120^{\circ}$ on the subcutaneous pedicle. (Figure 4). ${ }^{8,9}$

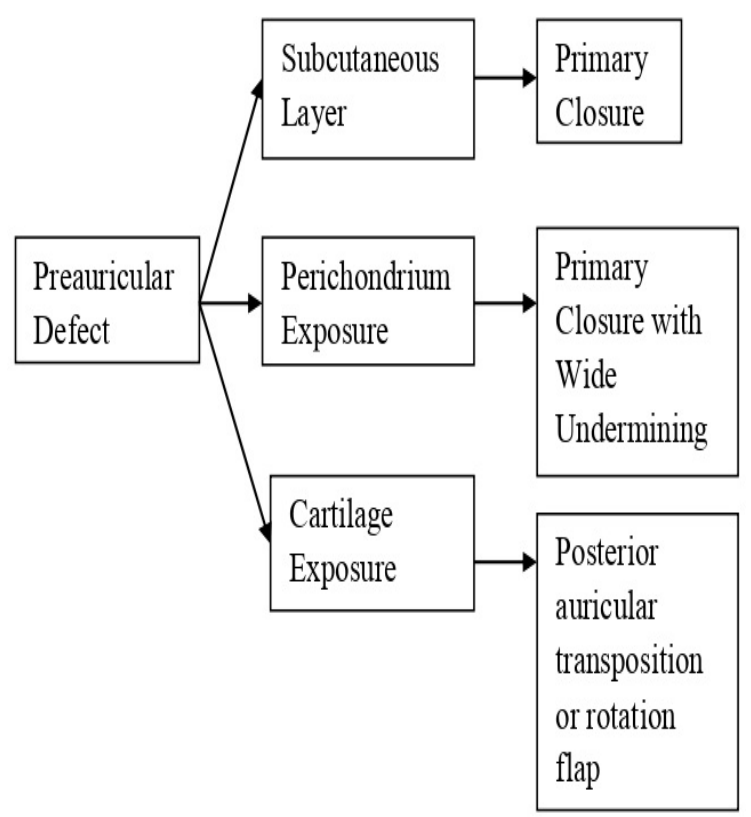

Figure 4. Framework of closing technique of defect after preauricular sinus excision. ${ }^{7-10}$

\section{CASE REPORT}

Reporting 4 surgical cases of prearicular fistula treated by plastic-reconstructive surgery, among 26 cases of preauricular fistula diagnosed between 2015 to 2017 in Cipto Mangunkusumo Hospital.

All procedures were performed under general anesthesia, followed by methylene blue dye injection into the opening of the fistula to trace the tract and sinus. After preauricular tract excision, primary closure, primary closure with wide undermining and posterior auricular flap using simple suturing were carried out to close the defect. 


\section{Case 1}

The patient was a 3 years old baby girl with a hole in front of her right ear since birth. There was a family history. The patient underwent a simple fistulectomy surgery. Before the incision, methylen blue solution was injected into the fistula tract. An eliptical incision was made around the fistule, and dissection was carried out to find the sac using "inside out" technique as shown in figure 5. The sac was located anterior of the medial supra auricle helix. The whole tract and sinus was totally removed, then the defect was undermined and sutured with prolen 5.0.
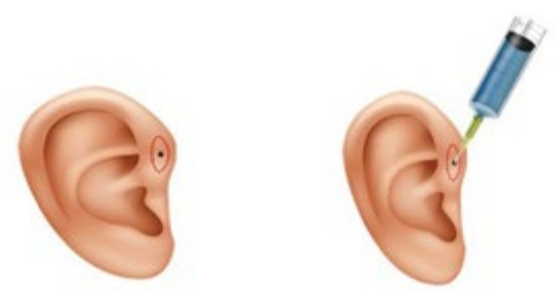

Figure 5. Ellipse incision and methylene blue injection

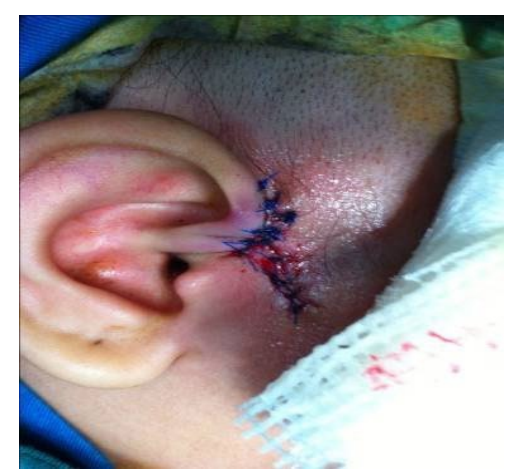

Figure 6. Post operative surgery eliptical incision, inside out technique

\section{Case 2}

A 18 years old girl came to PlasticReconstructive Division of ENT-HNS Department, with a chief complaint of recurrent ulcer in front of the left ear, which had occurred in the same spot since 3 years ago. She had a small hole in front of her left ear since birth, and from time to time there was a discharge from the hole. She was given antibiotic orally, but there but there was no improvement. Then, she was scheduled for a fistulectomy surgery.

Before the incision, methylene blue solution was injected into the fistula tract. An elliptical incision was made around the fistula, followed by dissection along the fistula tract. The location of the fistula tract was on the anterior of cartilage helix, and the medial border was temporal fascia. The fistula contained pus. The whole tract and sinus was removed totally. Drain was inserted to the posterior auricle and the defect was then sutured.

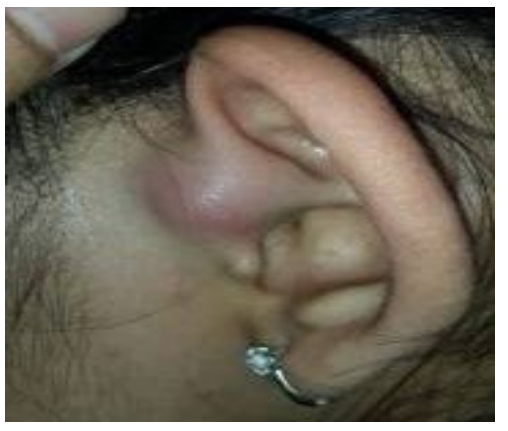

Figure 7. Preoperative case 2

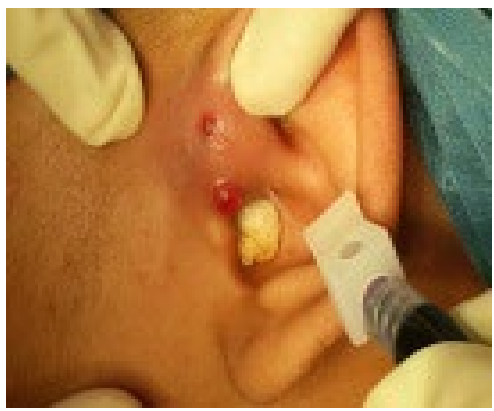

Figure 8. Patient with methylene blue

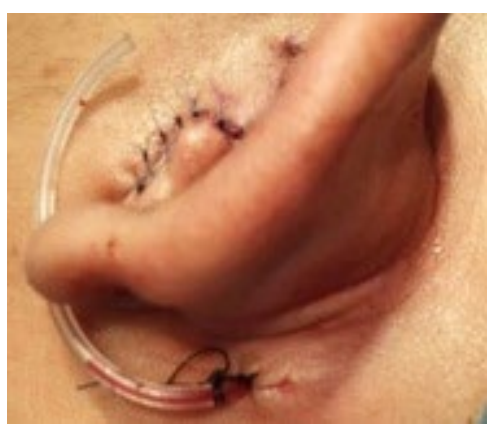

Figure 9. Post operative case 2 


\section{Case 3}

A 44 years old male patient, came with a hole in front of the right ear which present since birth. There was a history of itching and discharge a few years before.

A preauricular fistula was found in the anterior helix. There were no sign of edema, hyperemia, nor secretions from the fistula at that time.

The patient underwent surgery with supra auricular approach. Methylene blue was injected into the fistula tract. An extended elliptical incision around the sinus orifice was made, and the flap was undermined proceeded upward to the supra- and posterior auricular temporal region. This allowed better surgical view without adverse aesthetic consequences. $^{5}$

The sac was removed and a small piece of cartilage was resected. A drain was then inserted into the retroauricular region.

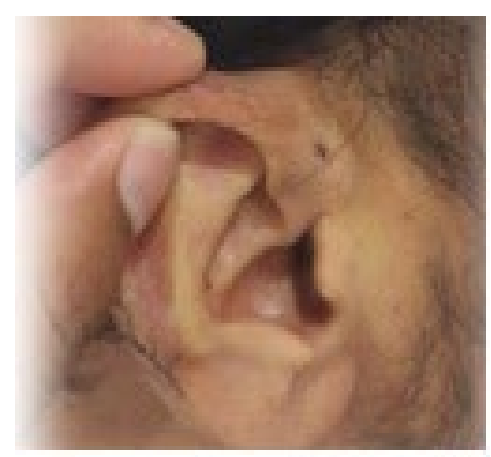

Figure 10. Preauricular fistula case 3

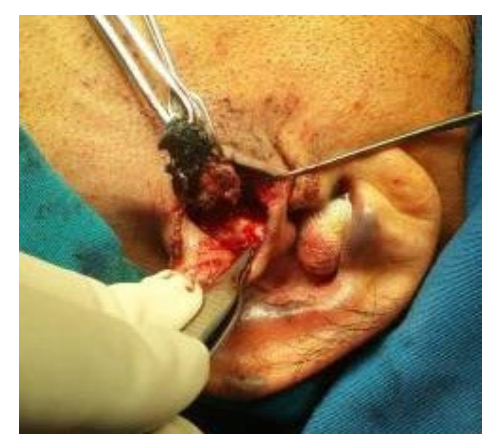

Figure 11. Extended elliptical incision case 3

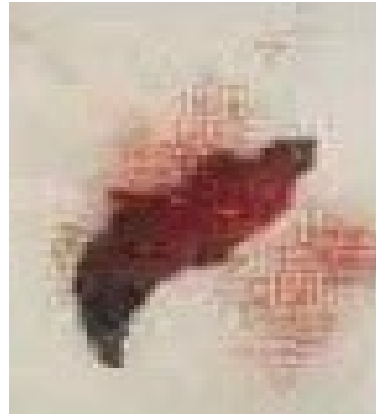

Figure 12. Fistula after resection

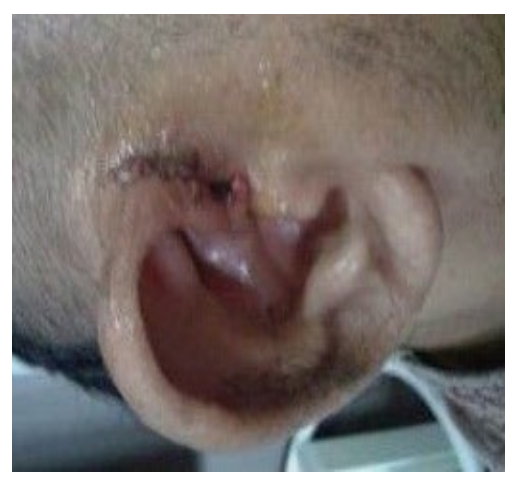

Figure 13. Post operative fistulectomy with supra auricular approach and drain insertion in case 3

\section{Case 4}

A man aged 25 years complained of recurrent infections in a hole in front of his left ear. He had undergone several surgeries for it. On ENT examination, there was a scar in front of the left ear. The patient underwent surgery with supra auricular approach. An elliptical incision extended down to the superior end of the tragus and up parallel to the anterior edge of the anterior helix was made around the fistula. The incision was deepened up to the temporalis fascia as a border of dissection. The dissection continues over the cartilage of the anterior helix. The base of the sinus attached to the perichondrium of the anterior helix was excised with the perichondrium to complete excision of the epithelial lining. After fistulectomy, the wound was closed with supraauricular advancement flap . 

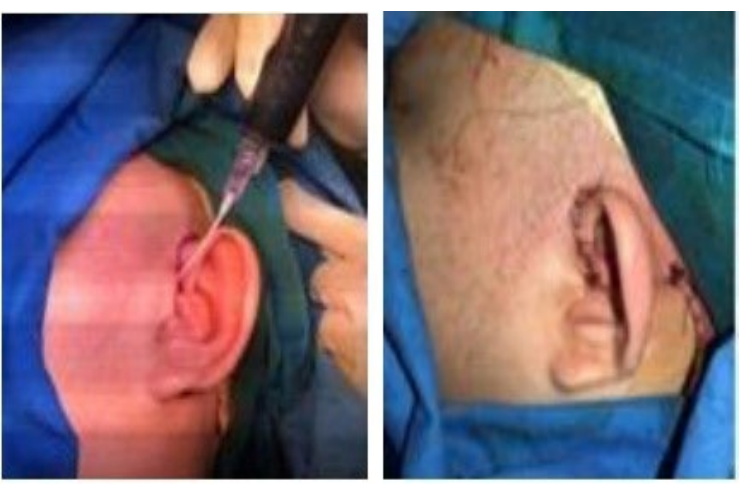

Figure 14. Scar and recurrent preauricular fistula in case 4

\section{CLINICAL QUESTION}

In preauricular fistula removal, does the supra-auricular approach produce lowest complication and recurrence compared to the elliptical incision techniques?

\section{METHOD}

Patient: Patients with preauricula fistula (adults and children). Intervention: Supraauricular approach. Comparison: simple fistulectomy. Outcome: Lowest complication and recurrence rate.

Literature research through Pubmed, Wiley, Proquest, and Google Schoolar with keywords of "Preauricular fistula AND surgical treatment" revealed 10 literatures (in Pubmed), 1 literature (in Wiley) and 1 literature (in Proquest). The selection based through 2012-2017 publication dates, English language, and free full text. Selection again through the clinical question, the result is one journal titled: "A Systematic Review on the Surgical Outcome of Preauricular Sinus Excision Techniques", stated that supraauricular approach could be the preferable technique for preauricular sinus removal. ${ }^{11}$

Bruijnzeel et all. ${ }^{12}$ conducted a systematic search from the PubMed and EMBASE databases on March 20, 2015 (Appendix 1). Both title and abstract and full-text screening were based on predefined inclusion and exclusion criteria Fourteen high directness of evidence studies were included. Complication rates were similar: sinectomy [0-31.4\%] and supra-auricular approach [0-18.2\%]. Recurrence rates showed that sinectomy resulted in significanty different $(\mathrm{p}<0.05)$ more recurrence 5.5\% (95\% CI 3.6-8.3\%) than Supra auricular approach $2.2 \%(95 \%$ CI 0.7-7.0). Sinectomy using the microscope resulted in the lowest sinectomy recurrence rates $(1.9 \%)$. Supra auricular approach in combination with a Penrose drain resulted in $0 \%$ recurrence in revision cases. Drain use resulted in the lowest supra auricular approach recurrence rates.

\section{DISCUSSION}

In the acute phase of infection, treatment comprises of administration of appropriate antibiotics, and drainage of abscess if present using lacrimal probe via preauricular pit. The aim of the surgery is to remove the sac and tract epithelial lining completely. An incomplete removal of sinus tract can cause recurrence. ${ }^{11}$

Defects after preauricle fistule excision are generally closed with simple primary closure and this frequently causes wound dehiscence due to the tension suture. The wound infection may worsen, with the development of chondritis, because the area is adjacent to the cartilage. This complication can be reduced by determining the best approach for the treatment: primary closure with wide undermining, or the use of a posterior auricular flap in cartilage exposure. Closing technique depend on the degree of tension and the depth of the defect. ${ }^{12,13}$

The reconstruction technique suggested in this paper has the advantage of being applicable to various excision methods, and a flap of healthy tissue is required to cover the scar. Furthermore, because the posterior auricular area has a rich vascular supply, flaps from this area adhere well to other tissue, leading to higher success rates. ${ }^{13}$ 
There are many reports of supra-auricular approach by Prasad, ${ }^{7}$ which statistically has a lower recurrence rate than simple sinusectomy. Supra-auricular approach had significantly less recurrence rate with 3.3\% than simple sinusectomy. Supra auricular technique is advised in an attempt to reduce recurrence rate. The recurrence rate after surgery was $4.9 \%{ }^{5,6,14}$

This case report had presented 4 cases of preauricular fistula which had undergone excision procedure according to the plasticreconstructive algorithm. All surgery measures were performed under general anesthesia. There was no recurrency after surgery.

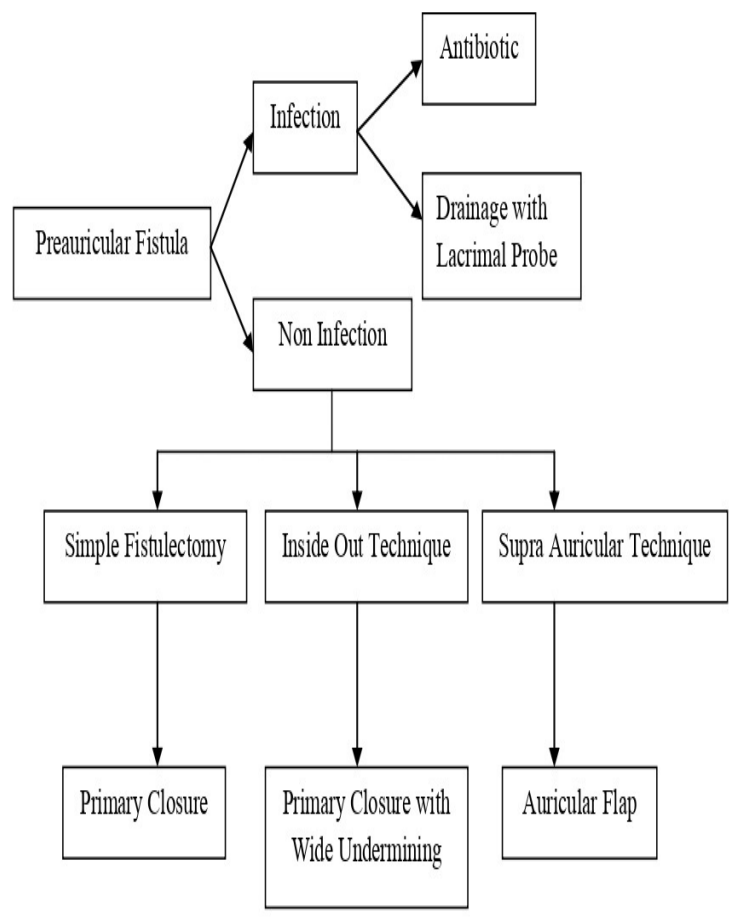

Figure 15. Plastic-reconstructive algorithm of preauricle sinus excision

\section{REFERENCES}

1. Lee KY, Woo SY, Kim SW, Yang JE, Cho YS. The prevalence of preauricular sinus and associated factors in a nationwide population-based survey of South Korea. Otol Neurotol 2014;35:1835-38

2. Austin DF. Telinga: Anatomi dan embriologi. Dalam: Ballenger JJ, editor. Penyakit Telinga Hidung Tenggorok Kepala dan Leher. Jakarta: Binarupa Aksara 2010. 101-51.

3. Coatesworth P, Patmore H, Jose J. Management of an infected preauricular sinus, using a lacrimal probe. J Laryngol Otol. 2003;117:983-4.

4. De Jong RJB. A new surgical technique for treatment of preauricular sinus. Department of Otolaryngology and Head Neck Surgery. The Netherlands: Elsevier 2005.567-70

5. Chan KC, Kuo HT, Ho WY, Chuang WY, Chen ZC. A modified supra-auricular approach with helix cartilage suture for surgical treatment of the preauricular sinus. Int $\mathrm{J}$ Pediatr Otorhinolaryngol. 2018;114:147-52.

6. El Assar AS, Hady MA, Askar SM, Amer HS, El-Anwar MW. Preauricular sinus: a comparative study between different surgical approach. Indian J Otol. 2017;23:193-6

7. Prasad S, Grundfast K, Milmore G. Management of congenital preauricular pit and sinus tract in children. Laryngoscope 1990;100:320-1

8. El-Anwar MW, ElAssar AS. Supraauricular versus sinusectomy approacher for preauricular sinuses. Int Arch Otorhinolaryngol. 2016;20:390-3.

9. Rataiczak H, Lavin J, Levy M, Bedwell J, Preciado D, Reilly BK. Association of recurrence of infected congenital preauricular cysts following incision and drainage vs fine-needle aspiration or antibiotic treatment. J Otolaryngol Head Neck Surg. 2017;143(2):131-4.

10. Lee JM, Yang HJ, Kim JH. Reconstruction Techniques for Tissue Defects Formed after Preauricular Sinus Excision. Arch Plast Surg. 2014 Jan; 41(1): 45-9; 
11. Huang WJ, Chu $\mathrm{CH}$, Wang $\mathrm{MC}$, Kuo CL, Shiao AS. Decision making in the choice of surgical management of preauricular sinuses with different severities. Otolaryngol Head Neck Surg. 2013;148(6):959-64

12. Bruijnzeel H, Aardweg MT, Grolman W,Stegeman I, Veen EL. A Systematic Review on the Surgical Outcome of Preauricular Sinus Excision Techniques. Laryngoscope 126: July 2016.
13. Chowdary KV, Chandra SN, Madesh KR. Preauricular sinus: a novel approach. Indian J Otolaryngol Head Neck Surg. 2013;65(3):234-6.

14. Tan B, Lee TS, Loh I. Reconstruction of preauricular soft tissue defects using a superiorly based advancement scalp flap. Am J Otolaryngol. 2018;39(2):204-7 